DigitALCOMMONS @WAYNESTATE-
Michigan Journal of Counseling:

Research, Theory and Practice

Volume 35 | Issue 1

Article 4

$8-1-2008$

\title{
Cyber Pox: A Look at Female Adolescent Cyber Bullying
}

Helen M. Garinger

St. John's University, garingeh@stjohns.edu

Follow this and additional works at: https://digitalcommons.wayne.edu/mijoc

\section{Recommended Citation}

Garinger, H. M. (2008). Cyber Pox: A Look at Female Adolescent Cyber Bullying, Michigan Journal of Counseling, 35(1), 24-32. doi: $10.22237 / \mathrm{mijoc} / 1217548980$

This Article is brought to you for free and open access by the Open Access Journals at DigitalCommons@WayneState. It has been accepted for inclusion in Michigan Journal of Counseling: Research, Theory and Practice by an authorized editor of DigitalCommons@WayneState. 


\section{Cyber Pox: \\ A Look at}

Female Adolescent Gyber Bullying

\section{Helen M. Garinger, Ph.D.}

St. John's University

Contact the authors at:

garingeh@stjohns.edu

Fax (718) 9907468
Bullying can be verbal, physical, or virtual. Researchers and the media have increasingly publicized negative consequences of electronic bullying in schools. The complexity of cyber bullying presents even more difficult issues than schoolyard bullying. Combating the bully, assisting the victim, and empowering the bystander are constant challenges for school counselors and school personnel. This article discusses aspects of cyber bullying and presents some prevention and intervention strategies for school counselors and parents.

Key Words: Cyber Bullying, bullying, relational aggression, school counselors, technology ullying is no longer limited to direct physical or verbal confrontations in the schoolyard. Technology has enabled bullying to expand into cyber space. The power of the Internet and its influence on the lives of teens should not be underestimated. In an adolescent world dominated by peer pressure, electronic connections pose an element of danger. Computer access is readily available in schools, public libraries, and the home.

Regardless of race, culture, or ethnicity the goal for school personnel remains to develop successful intervention strategies to combat bullying and cyber bullying, to constructively work with bullies, engage the bystanders, empower victims, and keep students safe. This article discusses aspects of bullying found in cyber bullying and presents prevention and intervention strategies for school counselors and parents.

\section{Cyber Bullying Defined}

Cyber bullying utilizes communication and information technologies. Cyber bullying is a covert form of psychological bullying. It can be verbal, utilizing a cell phone or written messages. Electronic media such as cell phones, websites, chatrooms, "MUD” rooms (multi-user domains where individuals can assume different names and characters) and online personal profiles, such as MySpace.com, enable bullies to hide behind screen names whereby they can remain anonymous (Shariff \& Johnny, 2007).

The critical difference between cyber bullying and regular bullying rests with the balance of power between the bully and the victim. Cyber bullying involves more victims than in-school bullying. Empowered by anonymity, a victim at school can become the tormenter from home. Anonymous perpetrators can transmit personal attacks in seconds. Perhaps, the most frightening aspect is the rapidity and scope of the email distribution (Willard 2007b). No longer is an incident confined between two students. Now the entire school population is there to witness the harassment and become privy to defamatory remarks about a classmate. "The Internet has unleashed its dark side, an underground, adolescent world of spite and vengeance. It is the bathroom wall moved into everybody's bedroom." (Cooper, 2004, p. 1).

Invariably, cyber bullying occurs without adults 
present, usually from a bedroom computer. And, the bully in school can continue attacking anyone from home. Schoolyard bullies are easily identifiable. Tracing a cyber bully is more difficult. The author learned that websites, such as Wiredsafety.org are used to track cyber attacks. Local authorities can also be involved. "Cyberspace represents new territory for peer mistreatment, often leaving school administrators with doubts about the boundaries of their jurisdiction" (Strom \& Strom, 2005, p. 36). "Virtual violence on the electronic media in the USA seems inescapable" (Jambor, 1996). Children tend not to share cyber bullying incidents with their parents for fear that they may interfere, which could make the bullying worse, or that their parents will punish them, or restrict their use of technology (Keith \& Martin, 2005). So, in spite of being a victim of cyber bullying or cyber threats, the child or adolescent is more fearful of restricted Internet use than sharing the issue with an adult. Staying connected is the lifeline to their social groups.

Some students tend to be targets of Internet abuse and others are not. Sometimes victims are simply those students who do not conform to the norms of the peer group, or the dominant group. They can be regarded as misfits for any number of reasons, such as bad teeth, hairstyle, clothes, or being too fat, or too thin. A student's behavior can be the source of future bullying, for instance, if a student cries too easily in class, he or she may become victimized.

\section{Identification of Victims and Consequences of Bullying}

Girls, who have difficulty regulating their emotions, feelings, and communicating effectively, are easy targets for victimization by peers (Duncan, 2004). Rigby (1993) noted that victimized girls report having a more negative attitude toward their mothers than do nonvictims. These girls described their mothers as hostile and rejecting toward them. The mothers threaten to reject and abandon their daughters when they misbehave. Such treatment inclines the victim toward depression, anxiety, or exhibiting other internalized symptoms (Duncan). These girls have no emotional anchor or stability in their lives. Rejected by their mothers, these girls have difficulty establishing a positive self-image. In contrast, boys who are victimized by bullies usually tend to be too closely attached to their mothers. Their mothers may be overly protective and baby them (Olweus, 1993). In either case, the outcome for the victim is the same: becoming alienated from peers, socially ostracized, and suffering as the result of their victimization.

The consequences of bullying are severe for those victimized over long periods of time. Cyber bullying likely causes the same emotional damage to its victims as regular bullying, but longitudinal studies have yet to be done. Leckie (2004) states an essential component to bullying is the intent to harm. Simmons (2002) claims that bullied victims carry emotional scars and have adjustment difficulties that continue into their adulthood. Tannenbaum (1999) states that negative reactions linger, and the victim has difficulty recovering from being taunted and ostracized by other girls.

"Research has consistently shown that children who are bullied are at an increased risk for negative psychosocial outcomes” (Raskauskas \& Stoltz, 2007, p. 566). Their findings show that the consequences are similar and negative for traditional or electronic bullying.

An example of cyber bullying devastation was reported in The New York Times (Maag, 2007). The story stated that a 13 year-old girl committed suicide due to cyber bullying. She had been diagnosed as depressed early in elementary school. The victim's mother wanted her daughter to find friends and gain popularity on-line. She lied so her daughter could sign up for MySpace before she was 13 . Her mother allegedly monitored her daughter's MySpace site, reading her emails. After the tragedy, the authorities discovered that a classmate's mother, who posed as a 14 year-old boy, had generated the emails as a joke. The boyfriend's on line emails deteriorated from romance to taunts and defamation, consequently pushing an unstable, depressed child to suicide.

Using words to inflict harm is socially unacceptable. The powerful words of a sage fifteen year old posted on a blog clearly stated that the responsibility of Internet usage is the individual's responsibility. Apparently this adolescent has more insight and awareness than the woman who posed as a fourteen year-old boy. The girl claimed to have been bullied and cyber bullied. She reported that it hurt her, and that people really are not different online. However, who they truly are is revealed by what they write on line. She concluded by stating that the root of the problem is the people using the technology and not the technology (Parker-Pope, 2007).

According to Willard (2007a), girls are more involved Michigan Journal of Counseling • 35:1 • August 2008 
in verbal communication than boys. Girls are more inclined to communicate online, whereas boys prefer to play games on line.

\section{The Role of Relational Aggression}

Relational aggression is another form of bullying, predominant and characteristic among middle school girls (Dellasega \& Nixon, 2004). The goal of relational aggression is to hurt others by damaging their reputation or their relationships (Espelage, Mebane \& Swearer, 2004). In addition to verbal communication, relational aggression primarily involves physically rejecting, snubbing, or excluding someone. Girls who are victims of relational aggression experience social distress and anxiety.

Cyber bullying is a more sophisticated weapon for verbal assaults and relational aggression than hurling insults at school. Malicious websites, defaming a girl's character, are newer tools for bullying tactics. The author believes that relationally aggressive behaviors are easily transferable to cyber bullying. Facebook or MySpace can be used to spread rumors, change someone's profile or fabricate stories about a classmate's sexual or other behavior. Children engage in this on line behavior because they have a false sense of power and security, enabling them to say or do things they never would if they were face-to-face (Simmons, 2003). These bullies believe they are protected in cyberspace and are not responsible for what they say or do. They have a sense of being invisible. And, being invisible is a powerful attribute.

Ringrose (2006) points out that media reports indicate there is a rise in female aggression. In another publicized incident, (Cave, 2008) eight students were involved in the beating of a Florida teen, who had used the internet to spread rumors about six girls. Two boys stood guard while the six beat the victim and recorded the encounter so that the incident could be shown on YouTube. The victim started the incident, by her postings on the Internet about the six girls. The girls, who beat her, reacted in an entirely unacceptable way. They may have considered themselves justified, but a beating is reprehensible. These six were unable to express their emotions in an appropriate way, through discourse, mediation, or seeking adult assistance and intervention. Their complete lack of judgment and savage behavior is shocking. The tormenter became the victim of revenge. Her bullying behavior was not denounced, but seems to be lost in this horrific story. Physical brutality is in no way a socially acceptable or appropriate response. The anger and aggression these girls vented is most disturbing. Apparently extreme violence has become so commonplace and prevalent that few are shocked. One perpetrator asked if she could attend her cheerleading practice after she was arrested. For the author, the most disturbing aspect of this incident is that two boys stood guard while the beatings and video tapings occurred. As bystanders, they could have stopped the six girls. Instead, they became accomplices.

\section{The Role of Bystanders}

Frequently, bullying incidents involve a third party, a bystander. Bystanders are identified as the students who are neither the bully nor the victim and play an important role by their physical presence during a bullying episode. Peer groups reject certain individuals who will eventually become a bully's victims (Doll, Song \& Siemers, 2004). Some bystanders encourage the bully, others watch bullying from the sidelines, but do nothing to help the victim. And, some bystanders make a difference by taking action and intervening during a bullying incident.

Electronic bystanders have a different, yet similar role. Bystanders' intervention can prevent emails either from being sent or being forwarded. If bystanders encourage the cyber bully, the bystander's action empowers the bully. At this point, the author believes, they are no longer bystanders, but should be regarded as colluding with the bully. In any event, direct cyber threats need to be reported to the authorities, just as disturbing material read on line should be reported to the police or school officials (Willard, 2007a). When bystanders intervene during a bullying episode, their action plays a critical role in ending the bullying cycle. The same could be said for cyber bullies and their bystanders. Students present should intervene, or seek adult intervention.

\section{Interventions and Solutions}

Numerous programs combating bullying online and in school abound with useful information for counselors, school personnel, parents and children of all ages. Many anti-bullying programs include videos and manuals to educate the entire school community (see appendix). Safe Internet use is of primary concern and can be presented in school during basic Internet skills instruction. If students receive emails, they have options not to forward the message, print them as evidence, or delete them. Initially, the cyber bully is more difficult to identify than the schoolyard bully but, once found, 
the cyber bully, just like the schoolyard bully, needs help. If a counselor can create a meaningful relationship with a bully and select an appropriate intervention, behaviors can change and everyone benefits.

By preventing schoolyard bullying, school staff and administrators can prevent cyber bullying. Counselors can create a variety of programs and discussion groups that target interventions like empathy training, anger management, and social skills building.

School personnel need to initiate programs that assist children and adolescents to become more aware of their feelings and help them become empathic. Some anti-bullying programs promote empathy training (Espelage et al., 2004). Empathy serves as a basis for understanding relationships, particularly when an action has caused harm (Willard, 2007b). Instruction in modeling empathic behavior provides children with guidelines for becoming sensitive and helping them manage anger and aggression. These programs create a more harmonious atmosphere in a school benefiting everyone and strengthening learning.

The author hypothesizes that by increasing empathic awareness, school personnel will encourage and train bystanders to become part of the solution. The one major obstacle when working with bystanders is to persuade students to "snitch" or break the code of silence. Unfortunately, in more than one school shooting incident, the perpetrator told friends, who in turn did not report or share the information with an authority figure. Disaster ensued that could have been averted had students "snitched." Being regarded as a snitch is social suicide. Tattling, often relegated to elementary school students, "is typically used only to get someone else in trouble” (Spitalli, 2003, p. 56). There is a difference between the tattletale and preventing character defamation, or worse. Counselors are in the position to clarify the distinction between tattling and sharing potentially lifethreatening information. This is no easy task and will take relationship building and trust between students and staff.

The author feels that another area in which counselors can assist is working with difficult students and teaching them how to manage and channel their anger in more constructive ways. Feelings of anger and rage eventually erupt and can lead to subversive use of the Internet or other electronic devices. Anger management programs have been cited as remedies to combat bullying and aggressive behavior (Espelage et al., 2004). Some children and

adolescents need training and modeling in order to guide them in their use of anger. An anger management group led by the school counselor provides information, discussion, and training to students who need help to control their rage. At the same time, students learn that anger is a normal emotion.

Social skills groups offer additional help to students. These groups can indirectly reinforce empathy training and offer appropriate outlets to divert excess anger and frustration without students bullying classmates. Social skills groups cover a broad range of skill development. Consistent group training in empathy, anger management, and social skills should mitigate detrimental, aggressive behavior. Counselors need to assist students face to face, in the real world, to better assist them in their virtual one. Further research is needed to determine the efficacy of intervention programs and 
social skills groups targeting bullying behavior.

An intervention technique counselors utilize when working with younger children is play therapy. Enacting life situations through play releases emotions. Similarly, the use of puppets and role-playing enables children to constructively work through their angry feelings and emotions. Some older students, middle and high school, may find it easier to utilize these techniques rather than verbal discussion. A student may feel safer or less threatened expressing his emotions through a puppet. Older students can keep journals or write letters as emotional outlets.

The author feels that schools can easily present programs devoted to Internet safety. For example, student groups can be lead by a counselor with open discussion devoted to electronic safety. Computer teachers can collaborate with counselors in computer classroom safety instructions. Asking students to answer the following questions honestly, counselors will aid

students in developing greater self-awareness, increase empathy, and initiate further thoughtprovoking discussions. The questions Willard (2007a, pp. 85 \& 86) posed: Am I being considerate of others? What would I feel like if someone did this to me, or my close friend? How does this make me feel? What would an adult, whom I respect and admire, think about my behavior? Would I feel differently if others could see me? What does this behavior say about me as a person? After each of these questions, counselors can ask students' opinions and discuss responses.

As noted earlier in regard to intervention programs, students cannot change their behavior alone. Adolescents need good role models. They need adults who exhibit positive behavior in their interactions in both the real and virtual world. Parents need to become educated and pro-active in their children's Internet activity. Schools can provide programs for parents that teach and train them in Internet usage. Bandura purports that children model behavior from their observations (Gardner, 1982). They learn aggressive responses by watching others, either personally within their families or through the media and social environment (Gardner). Therefore, parents and other adults modeling appropriate behavior are essential in children's lives. In addition, adults should talk to children about treating others with respect and kindness. This sentiment should be reinforced in the schools.

Belsey (2004) notes the difficulties in combating cyber bullying are compounded by the difference in the way parents and children relate to technologies. Both generations value the importance and necessity of using various technologies. Parents utilize computers coifficulties in combating cyber bullying are compounded by the difference in the way parents and children relate to technologies. Both generations value the importance and necessity of using various techmologies.

Parents utilize computers for workand practicaltasks. Children tend to stay connected with their peer group via the Internet.

Adults do not rely on cyber space to learn about the personal lives of their friends nor share secrets. Despite these differences, parents need to be knowledgeable about their children's Internet activities and what they are doing on line.

for work and practical tasks. Children tend to stay connected with their peer group viatheInternet(Keith \& Martin, 2005). Adults do not rely on cyber space to learn about the personal lives of their friends nor share secrets. Despite these differences, parents need to be knowledgeable about their children's Internet activities and what they are doing on line.

Parentscanbeencouraged to familiarize themselves with the web sites their children visit, and know their child's usernames and password. Computers should beplaced in common areas, such as a den, not in bedrooms. Having the computer in a more trafficked area of the home will enable parents to better monitor on line behavior. Parents can purchase monitoring software that records all online activities. 
Helen M. Garinger, Ph.D.

Children should learn that cyber bullying can lead to criminal arrest (Willard, 2007b). There are a number of instructive on-line communities that have chat groups and question/answer help. How children would respond to their parents' involvement in their on-line behavior could lead to interesting conversations. Further research is needed on this subject.

The Center for Safe and Responsible Internet Use is an on line resource that discusses many aspects of cyber bullying, as well as, provides guidelines for parents and students on how to address cyber threats and cyber bullies. The Center encourages students not to give personal contact or other intimate information on line. Cyber Angels is another website designed for both students and parents use. Again, the message is to educate both adults and children and answer questions for all involved using the Internet.

School personnel need to create an atmosphere that promotes unity among adults and students. To begin building a relationship, caring adults want to listen to students, take students' opinions into consideration when making policy, and invite students to participate in an advisory capacity (Spitalli, 2003). Student involvement and empowerment allows students to see that adults respect their viewpoints, value their contributions, and understand their needs. Mutual respect enables students to share concerns with faculty and staff. Just as any other policies are tried, student ideas should become programs or policy and subsequently evaluated.

Another way faculty can build their relationships with students is when teachers make an effort to attend extracurricular school activities like student sports events or performances. The presence of teachers shows students that they are interested in them on a personal level, outside the classroom. In addition, having school personnel more involved, engaged, and visible in the halls ensures the feeling of safety for students (Spitalli, 2003). If a cyber bullying incident occurs and a good trusting relationship exists, students are inclined to tell an adult immediately. Building a relationship and succeeding in open communication between students and adults is of critical importance.

\section{Conclusion}

With the aid of technology, bullying has become more complex and invasive. The rapidity and scope of Internet postings truly devastates victims. The anonymity of cyber bullying gives the tormenter more power than the schoolyard bully.

Bullying is a learned behavior and can be altered if consistent, appropriate behavior is modeled. School counselors can provide empathy training and anger management programs teaching and reinforcing prosocial skills to enable the cyber bully to release and explore feelings of anger and aggression. The goal is for increased self-understanding and development of socially appropriate skills.

Working as a team, all school personnel, and vigilant parents can remediate this situation. They need to convey the message that any type of bullying will not be tolerated. Together counselors, teachers, and parents can instruct children in safe and responsible Internet use. Children and adolescents need adults in their lives who will work with them to make their world safe from bullies. 


\section{References}

Belsay, W. (2004). Cyberbullying: An emerging threat to the "Always on” generation. Retrieved 12/2/ 05, from http:// www.cyberbullying.ca.

Cave, D. (2008, April 12). Eight teenagers charged in Internet beating have their day on the web. The New York Times. Retrieved on April 12, 2008 from http://nytimes.com

Cooper, C. J.(2004). Cyber-bullies stalking online playground. The Record. Bergen County, N.J. Retrieved 12/18/07 from http://www.azcentral.com/php-bin/clicktrack/print.php?referer=http://www.azcentral.com/families/ articles/0421cyberbullies21-ON.html

Dellasega, C. \& Nixon, C.. (2003). Girl Wars: 12 strategies that will end female bullying. NY, NY: Penguin Books.

Doll, B., Song, S. \& Siemers, E. (2004). Classroom ecologies that support or discourage bullying. In D.L. Espelage \& S.M. Swearer (Eds.), Bullying in American Schools: A social-ecological perspective on prevention and intervention. (pp. 161-184). Mahwah, NJ: Lawrence Erlbaum Associates, Publishers.

Duncan, R. (2004). The impact of family relationships on school bullies and their victims. In D.L. Espelage \& S.M.

Swearer (Eds.), Bullying in American Schools: A social-ecological perspective on prevention and intervention. (pp. 227244). Mahwah, NJ: Lawrence Erlbaum Associates, Publishers.

Espelage, D. L. , Mebane, S., \& Swearer, S. M. ( 2004). Gender differences in bullying: Moving beyond mean level differences. In D.L. Espelage \& S.M. Swearer (Eds.), Bullying in American Schools: A social-ecological perspective on prevention and intervention. (pp. 15-36). Mahwah, NJ: Lawrence Erlbaum Associates, Publishers.

Gardner, H. (1982). Developmental Psychology (2nd ed.). US \& Canada: Little, Brown \& Company.

Jambor, T. (1996, October). The present situation of youth and sociability and relevant problems in the USA. Paper presented at the International Forum on Youth '96, Gifu, Japan.

Keith, S. \& Martin, M.E. (2005). Cyber-bullying: Creating a culture of respect in a cyber world. Reclaiming Children and Youth. (13)4, 224-228.

Leckie, B. (2004). Girls, Bullying Behaviours and Peer Relationships: The double-edged sword of exclusion and rejection. Retrieved 12/19/04 from University of South Australia, Flinders University

Maag, C. (2007, December 16). When the bullies turned faceless. The New York Times, Style Section, p. 9. 


\section{References}

Olweus, D. (1993). Bullying at school: What we know and what we can do. Malden, MA, Oxford, UK, Australia, \& Germany: Blackwell Publishing.

Parker-Pope, T. (2007, November 27). More Teens Victimized by Cyber-Bullies. New York Times Blog: Posting by Nicole, Retrieved on January 11, 2008 from http://nytimes.com

Raskauskas, J. \& Stoltz, A. (2007). Involvement in traditional and electronic bullying among adolescents. Developmental Psychology. 43(3), 564-575.

Rigby, K. (1993). School children's perceptions of their families and parents as a function of peer relations. The Journal of Genetic Psychology, 154, 501- 513.

Ringrose, J. (2006). A new universal mean girl: Examining the discursive construction and social regulation of a new feminine pathology. Feminism \& Psychology. 16(4), 405-424.

Sharif, S. \& Johnny, L. (2007). Cyber-Libel and cyber-bulling: Can schools protect student reputations and free-expression in virtual environments? Education Law Journal. 16(3), 307- 343.

Simmons, Rachel. (2003, September 23). Cliques, Clicks, Bullies And Blogs Retrieved 6/ 30/ 05, from The Washington Post: http://www.washingtonpost.com/ac2/wp-dyn?pagename=article\&contentId=A8020-2003Sep26

Simmons, Rachel. (2002). Odd girl out: The hidden culture of aggression in girls. NY, San Diego \& London: Harcourt.

Spitalli, S. J. (2003). Breaking the code of silence: How students can help keep schools - and each other- safe. American School Board Journal. September. 56-58

Strom, P.S. \& Strom, R.D. (2005). When teens turn cyberbullies. Retrieved 8/30/07, from The Education Digest. Condensed from the Educational forum, 70, 21-36

Tannenbaum, L. (1999). Slut! Growing up Female with a bad reputation. New York: Seven Stories Press.

Willard, N. (2007a). Cyberbullying and cyberthreats: Responding to the challenge of online social aggression, threats, and distress. Champaign, IL: Research Press.

Willard, N. (2007b) Cyber-safe kids, cyber-savvy Teens: Helping young people learn to use the internet safely and responsibly. San Francisco, CA: John Wiley \& Sons, Jossey Bass. 